\title{
Linking Ecosystem Services, Rehabilitation, and River Hydrogeomorphology
}

JAMES H. THORP, JOSEPH E. FLOTEMERSCH, MICHAEL D. DELONG, ANDREW F. CASPER, MARTIN C. THOMS, FORD BALLANTYNE, BRADLEY S. WILLIAMS, BRIAN J. O'NEILL, AND C. STEPHEN HAASE

Assignment of values for natural ecological benefits and anthropocentric ecosystem services in riverine landscapes has been problematic, because a firm scientific basis linking these to the river's physical structure has been absent. We highlight some inherent problems in this process and suggest possible solutions on the basis of the hydrogeomorphic classification of rivers. We suggest this link can be useful in fair asset trading (mitigation and offsets), selection of sites for rehabilitation, cost/benefit decisions on incremental steps in restoring ecological functions, and general protection of rivers.

Keywords: environmental benefits analysis, hydrogeomorphic patches, river management, river rehabilitation, riverine ecosystem synthesis

$\mathbf{R}$ iver ecosystems remain enigmatic to many people, and are often seen as offering fewer benefits to society compared with lakes or terrestrial habitats. This may soon change, however, because of a developing trend in environmental sciences to emphasize the benefits and services provided by aquatic and terrestrial ecosystems (e.g., Postel and Carpenter 1997, Loomis et al. 2000, Nelson et al. 2009). This trend includes evaluating attributes related to the natural functioning of rivers, such as species richness and nutrient cycling, and to anthropocentric properties, such as flood control and recreation.

Numerous government agencies responsible for protecting and rehabilitating rivers, including the US Environmental Protection Agency (EPA) and the US Army Corps of Engineers (USACE), are increasingly promoting projects evaluating ecosystem services. Government agencies in a few other countries, such as Australia, have also raised this banner, as have some nongovernment organizations (NGOs), including The Nature Conservancy and the World Wildlife Fund.

Individual environmental agencies and NGOs often employ different definitions of ecosystem services, and may aggregate them into dissimilar groups. For example, the USACE focuses on natural environmental benefits (e.g., biodiversity, nutrient cycling, etc.), whereas the EPA and the Millennium Ecosystem Assessment (MEA 2005) also include society services. We use the following definition: "Ecosystem services are the quantifiable or qualitative benefits of ecosystem functioning to the overall environment, including the products, services, and other benefits humans receive from natural, regulated, or otherwise perturbed ecosystems."

Benefits are frequently separated into "supporting services" (e.g., biogeochemical cycling, production, habitat or refugia, and biodiversity), "regulating services" (e.g., regulation of water quality, climate, floods and erosion, and biological processes such as pollination, pests, and diseases), "provisioning services" (direct or indirect food for humans, fresh water, wood and fiber, and fuel), and "cultural services" (e.g., aesthetic, spiritual, educational, and recreational). Monetary values are assigned to a subset of these services.

Benefits and services have become a hot topic in recent years (e.g., Turner et al. 2007, Costanza 2008, Naidoo et al. 2008) for various reasons. In the case of riverine landscapes, this emphasis helps demonstrate to the public and government leaders their crucial ecological role. This is especially important because of the little-appreciated fact that extinction rates for freshwater fauna in North America are estimated to be five times greater than those for North American continental 
terrestrial fauna-rates comparable to those in tropical forests (Ricciardi and Rasmussen 1999). A focus on ecosystem services may also promote alternative river management options, including river rehabilitation.

The USACE's objective in this area is related to mandates for national ecosystem restoration through improvement in the net quantity and quality of desired ecosystem resources, and the restoration of the dynamic functional and structural processes that have been degraded (Stahkiv et al. 2003). A national goal is to maximize public benefits like river access, education, and recreation, as well as traditional services related to flood damage control, ground water recharge, and others.

\section{Current policies and new directions}

Agencies responsible for river management have struggled with issues related to the evaluation of ecosystem services, rehabilitation, and fair asset trading (mitigation and offsets) because (a) appropriate river classification systems were unavailable or inadequately exploited, (b) techniques for evaluating services were underdeveloped, (c) effects of different types of river segments and river regulation on services were unappreciated, and (d) the role of whole river processes and the upstream-downstream effects of regulation were too often ignored. Although no single article can solve all these problems, our goals are to highlight some challenges and offer possible solutions. Our central approach relies on techniques for analyzing a river's hydrogeomorphic character (past, present, and possible future), associating this with habitat and niche complexity, and then linking these with the river's biocomplexity and ecosystem services, as described in part in the riverine ecosystem synthesis (RES; Thorp et al. 2006, 2008). Our focus reflects a widespread view that the prime driver of river ecosystem functioning is its hydrologic pattern (e.g., Poff et al. 1997, Hein et al. 2003) and the resulting hydrologic molding of the geomorphic and organic habitat template (Frissell et al. 1986, Townsend and Hildrew 1994).

\section{A river's hydrogeomorphic structure and its ecological implications}

Although the field of fluvial geomorphology is rich with models describing the structure and physical functioning of riverine landscapes, few geomorphic models have had significant impacts on lotic ecology. The most prominent exception is the river continuum concept (Vannote et al. 1980), which emphasized a gradual and more or less continuous physical gradient from headwaters to the mouth, interrupted secondarily by local differences in geologic features and tributaries. More recently, rivers have been portrayed as a network of main channels and intersecting tributaries (Benda et al. 2004), with tributary junctions serving as ecological hot spots. A third structural model of fluvial systems emphasizes hydrogeomorphic patches at various spatial scales and focuses on ecosystem structural and functional responses to local features of the fluvial landscape (Montgomery 1999, Rice et al. 2001, Poole 2002, Thorp et al. 2006).
At the valley-to-reach scale, which is most appropriate for riverine management (Thorp et al. 2008), these patches are termed functional process zones (FPZs; Thoms and Parsons 2003). "Reach" is the smallest spatial unit above a single riffle or pool. These FPZs are statistically delineated but can be visualized as braided and meandering sections, to cite two generalized examples. In the RES model, FPZs are considered repeatable along a river's longitudinal dimension and only partially predictable in location, especially above the ecoregional level (figure 1). Patch models (Poole 2002, Thorp et al. 2006, 2008) suggest that local hydrologic pattern (e.g., Poff et al. 1997) and geomorphic conditions are more important to ecosystem structure and function than the longitudinal or network positions per se along a river's downstream path. Consequently, ecosystem processes should be less similar in an adjacent but distinct FPZs than in the same type of FPZ in a different region of the river.

\section{River characterization, or "typing"}

We recommend evaluating ecosystem services by describing the hydrogeomorphic character of the hierarchically arranged riverine landscape using various techniques of river typing. The services characterizing a river section reflect the spatiotemporal scale and the hydrogeomorphic features of the focal patch. When focusing on the small-reach level, a laborintensive but more precise field method (e.g., Rosgen 1996) may be appropriate. In contrast, when focusing on the larger valley-to-reach level, we recommend a cost-effective approach using advanced desktop computers, ArcGIS, DEM (digital elevation model) data, precipitation and geologic data layers, remote sensing imagery, and automated data extraction and manipulation programs (Thoms et al. 2007, Thorp et al. 2008). This approach functions at all spatial scales, from whole basins like the Kansas River (approximately 159,000 square kilometers [ $\left.\mathrm{km}^{2}\right]$ with less than 14,000 stream $\mathrm{km}^{2}$ ) down to the reach level of a third-order stream or lower. Our current approach employs 14 to 15 catchment, valley, and channel variables and statistical methods that allow FPZ type and distribution to emerge while minimizing investigator bias. This approach is not related to the hydrogeomorphic wetlands classification system (Brinson 1993), which includes alluvial wetlands.

\section{Linking hydrogeomorphology to ecosystem processes in natural systems}

All four common categories of ecosystem services (supporting, regulating, provisioning, and cultural) either specifically include components of biodiversity and ecosystem functioning or are affected by them. Research on relationships between hydrogeomorphic structure and ecosystem properties are largely in their infancy, and thus only tentative predictions can be made on relationships between FPZs and ecosystem properties (e.g., see figure 1). The RES, for example, includes 17 hypotheses, many of which link the hydrogeomorphic model with a range of ecological patterns and processes from species through landscapes (Thorp et al. 2008). In general, the 
RES predicts that biodiversity, system metabolism, and many other functional ecosystem processes are enhanced by habitat complexity at the valley-to-reach scale. Biocomplexity should be greater in FPZs that are more hydrogeomorphically complex (greater diversity of channels and flow conditions) than in simpler river segments (table 1) because of increased habitat diversity and greater niche availability.

\section{Goods, services, and the hydrogeomorphic structure of riverine landscapes}

Some ecosystem services should be enhanced up to a certain point (cf. Schwartz et al. 2000) by increased biodiversity and system metabolism (reflecting higher overall respiration and primary production). And, because the natural ecological functioning of rivers is related to hydrogeomorphic complexity (for comparisons among pristine systems), we derived the following general hypothesis: The levels of ecosystem services provided by riverine landscapes are an increasing function of the hydrogeomorphic complexity of the local functional process zones.

This hypothesis should prove valid for most of the ecosystem services listed in table 1. Exceptions would include, for example, material transport on barges, where stable, singlechannel systems are advantageous for navigation. Examples of possible relationships between hydrogeomorphic structure and ecosystem services within a single basin are shown in table 1 for six contrasting types of natural and artificial FPZs in a generalized river. This table is not meant to be definitive for services, and some predictions would be influenced by river size, ecoregion, and proximity to urban centers. This is especially true for anthropocentric services such as recreation and material transportation, for which a minimum depth is often required for barge traffic. It is also very important to note that the ecosystem benefits and services provided by a river as a whole are greater than those provided by either an individual FPZ or the sum of all services for all FPZs combined.

Table 1 includes only 5 of the 14 to 15 variables used to delineate FPZs in our river-typing methods, but these are sufficient to illustrate why ecosystem services should vary among FPZs. The first three geomorphic attributes directly influence the habitat template in rivers, and we predict that ecosystem structure and function are proportional to niche diversity and, thus, to the number of macro- and microhabitats. "Channel/island permanence" reflects both the bed movement and the presence of trees and other relatively long-lived vegetation on islands. For example, a braided river features many relatively short-lived islands with few if any mature trees. In contrast, anastomosing FPZs often have islands that are relatively stable between years and thereby support larger and more long-lived riparian flora. Finally, the attribute "floodplain size and connectivity with main channel" is useful for predicting biodiversity, carbon sequestration, and food and fiber production.

Predictions for natural ecosystem benefits in table 1 often follow hypotheses proposed in the RES on the effects of ecological habitat complexity (Thorp et al. 2008). We predict that



Figure 1. A conceptual riverine landscape is shown depicting various functional process zones (FPZs) and their possible arrangement in the longitudinal dimension. Not all FPZs and their possible spatial arrangements are shown. Note that FPZs are repeatable and only partially predictable in location. Information contained in the boxes next to each FPZ depicts the hydrological and ecological conditions predicted for that FPZ. Symbols are explained in the information key. Hydrological scales are flow regime, flow history, and flow regime as defined by Thoms and Parsons (2003), with the scale of greatest importance indicated for a given FPZ. The ecological measures (FCL, food chain length; NS, nutrient spiraling; $S p D$, species diversity) are scaled from long to short, with this translated as low to high for species diversity. The light bar within each box is the expected median, with the shading estimating the range of conditions. Size of each arrow reflects the magnitude of vertical, lateral, and longitudinal connectivity. Source: Revised from figure 1.1 and color plate 1 in Thorp and colleagues (2008). 


\begin{tabular}{|c|c|c|c|c|c|c|}
\hline Ecosystem services and benefits & Constricted & Meandering & Braided & Anastomosing & Leveed & Reservoir \\
\hline \multicolumn{7}{|l|}{ Selected hydrogeomorphic attributes } \\
\hline $\begin{array}{l}\text { Shoreline complexity (ratio of shoreline } \\
\text { length to downstream length) }\end{array}$ & L & LM & $\mathrm{H}$ & $\mathrm{H}$ & L & M \\
\hline Relative number of channels & L & $\mathrm{L}$ & $\mathrm{H}$ & $\mathrm{HM}$ & L & L \\
\hline Functional habitats within channels & L & LM & M & $\mathrm{H}$ & L & LM \\
\hline Channel/island permanence & M & M & L & $\mathrm{H}$ & M & $\mathrm{H}$ \\
\hline $\begin{array}{l}\text { Floodplain size and connectivity } \\
\text { with main channel }\end{array}$ & L & $\mathrm{MH}$ & M & $\mathrm{H}$ & L & L \\
\hline \multicolumn{7}{|l|}{ Natural ecosystem benefits } \\
\hline $\begin{array}{l}\text { Biodiversity (species richness and } \\
\text { trophic diversity) }\end{array}$ & L & M & L & $\mathrm{H}$ & L & M \\
\hline $\begin{array}{l}\text { Proportion of native biota (prior to } \\
\text { any change in FPZ) }\end{array}$ & $\mathrm{H}$ & $\mathrm{H}$ & $\mathrm{H}$ & $\mathrm{H}$ & L & L \\
\hline Primary and secondary productivity & $\mathrm{L}$ & M & M & $\mathrm{H}$ & L & $\mathrm{H}$ \\
\hline $\begin{array}{l}\text { Nutrient cycling and carbon } \\
\text { sequestration }\end{array}$ & $\mathrm{L}$ & LM & LM & $\mathrm{H}$ & L & $\mathrm{H}$ \\
\hline Water storage & $\mathrm{L}$ & LM & $\mathrm{L}$ & $\mathrm{H}$ & L & $\mathrm{H}$ \\
\hline Sediment storage & $\mathrm{L}$ & M & $\mathrm{M}$ & $\mathrm{H}$ & L & $\mathrm{H}$ \\
\hline \multicolumn{7}{|l|}{ Anthropocentric services } \\
\hline $\begin{array}{l}\text { Food and fiber production (agricultural } \\
\text { crop production excluded) }\end{array}$ & $\begin{array}{l}\mathrm{L} \\
\mathrm{MH}\end{array}$ & $\begin{array}{l}M \\
M\end{array}$ & $\begin{array}{l}\mathrm{L} \\
\mathrm{L}\end{array}$ & $\begin{array}{l}\mathrm{H} \\
\mathrm{M}\end{array}$ & $\begin{array}{l}\mathrm{L} \\
\mathrm{H}\end{array}$ & $\begin{array}{l}\mathrm{M} \\
\mathrm{H}\end{array}$ \\
\hline \multicolumn{7}{|l|}{ Water withdrawal potential } \\
\hline Recreation & LM & LM & L & $\mathrm{H}$ & $\mathrm{L}$ & $\mathrm{H}$ \\
\hline $\begin{array}{l}\text { Disturbance and natural hazard } \\
\text { mitigation }\end{array}$ & L & M & L & $\mathrm{H}$ & $\mathrm{H}$ & $\mathrm{H}$ \\
\hline $\begin{array}{l}\text { Maintenance and catastrophic } \\
\text { risk of failure }\end{array}$ & $\mathrm{N} / \mathrm{A}$ & N/A & N/A & $\mathrm{N} / \mathrm{A}$ & M & $\mathrm{H}$ \\
\hline Transportation & $\mathrm{H}$ & M & L & M & $\mathrm{H}$ & $\mathrm{H}$ \\
\hline
\end{tabular}

most natural benefits peak in the physically complex anastomosing FPZs (including anabranching systems), but reservoirs should also generally have high values. A prominent exception is the proportion of native fauna. This should be lower in reservoirs because (a) the environment shifts from primarily lotic to lentic conditions from impoundment, promoting selection for a different suite of species; and (b) species are often introduced for either sport fishery or consumption of nuisance aquatic vegetation. Biodiversity, as measured by species richness and trophic feeding diversity, is usually greater in physically complex FPZs (Roach et al. 2009) because habitat diversity is greater and opportunities for both fluvial and floodplain specialists abound (Galat and Zweimüller 2001). FPZs with a greater range of current velocities and substrate types offer habitat niches for a greater diversity and potential productivity of algae and vascular plants. Nutrient spiraling in rivers is heavily influenced by stream velocity and lateral storage. FPZs that are laterally complex and have greater floodscape connectivity should sequester carbon for longer periods throughout the permanently and periodically wetted portions of the riverine landscape. These FPZs should therefore transform more nitrates into nitrogen gas through denitrification within static pools and backwaters because of a greater abundance of anaerobic bacteria in the sediments. Water and sediment storage are influenced by lateral extent and connectivity within the riverine landscape (except for internal storage within reservoirs).

Ranking anthropocentric services by river hydrogeomorphology is more challenging than ranking natural benefits because anthrocentric services are heavily influenced by climate, river accessibility, and proximity to cities. These affect access to the services and perceived value. For example, noncrop food and fiber production depend partially on local water quality and climate. Water quality affects the acceptability of local fish as food for humans and livestock, and climate influences the types of plants that will grow in alluvial wetlands. Subsistence harvesting of food and fiber from riverine landscapes is likely affected by the rural nature of the FPZ. Water withdrawal potential depends on flow rates, ease of withdrawal, and storage capacity, with this service valued more in semiarid farming environments or near large urban centers. Recreational services can be consistently low for some FPZs (e.g., braided and leveed FPZs), consistently high in reservoirs (and probably to a lesser extent in anastomosing systems), and variable in others. As an example of the last, constricted FPZs are typically unexploited in many areas of the country, but at other sites 
(e.g., the Colorado River) they provide prime rafting areas. Physical access to anastomosing FPZs, with their plentiful side channels, can influence their use by boaters, hunters, and fishermen. Mitigation of disturbance and natural hazards, such as floods, are related strongly to the rate of water retention but sometimes for opposite reasons. For example, reservoirs and anastomosing FPZs can retain large amounts of water from a flood pulse and thereby reduce downstream flood problems. In contrast, leveed systems have minimal ability to retain water, but they can prevent local and upstream flooding, unlike reservoirs and anastomosing FPZs. However, artificial FPZs have higher maintenance costs and are more often subject to catastrophic failure.

\section{Costs of using and maintaining ecosystem services}

A typical approach for evaluating services is to classify habitats by some attribute (hydrogeomorphic structure in our case) and then link the resulting groups to particular services. While such "services-oriented" approaches are vital, they are misleading if cost/benefit analyses are neglected.

All FPZs provide some degree of natural ecosystem benefits and anthrocentric services, but engineered FPZs are more likely to require frequent cash inputs to maintain services. For example, leveed FPZs may have benefits nearly equivalent to those in naturally constricted or stable-sinuous FPZs of sufficient depth for transportation, but artificial FPZs require funds for initial construction and regular maintenance to sustain those services. Moreover, engineered FPZs are associated with high catastrophic risk from failure, especially when flood-prone areas are occupied behind levees. Reservoirs also may provide many services, including electrical generation, recreation, and water storage, but they are costly to build, maintain, and dredge. Failure of a reservoir's dam can lead to massive loss of human lives and property.

Although catastrophic failures are less commonly associated with natural FPZs, there are potential financial risks in exploiting their services. For example, a farmer may benefit from planting in the rich soil of floodplain bottomland, but high floods may destroy a year's crop. Likewise, homeowners may derive aesthetic and recreational value from living on a riverbank, but they face greater risks of flooded basements or loss of land or house.

\section{Asset trading (mitigation and offsets)}

Environmental mitigation involves minimization of damage to sensitive areas and improvement in the quality of other sites through environmental offsets - an approach not yet widespread in riverine landscapes. A number of federally supported rehabilitation (mitigation) projects are under way on sites where the natural FPZs have been extensively altered by dams or levees, but the scientific criteria for site selection is not always evident nor satisfactory for rivers and other ecosystems (cf. Daily et al. 2009). One recent technique involves dam removal (e.g., Casper et al. 2006), but this is typically divorced from issues of asset trading and often only involves medium or small streams.
Another challenge in effective asset trading is the lack of a strong scientific basis for trading improvements at one site for degradation at another. Environmental managers are often forced to rely on poorly developed principles of "benefit transfer" where the economic value estimates at one site are often applied to another without a firm knowledge of how site characteristics might change ecosystem services (cf. Plummer 2009). An inadequate knowledge base linking the physical characteristics of rivers with their natural ecosystem functioning and ecosystem services has made benefit transfer highly problematic.

Because FPZs differ in their natural ecosystem processes and anthrocentric services, the hydrogeomorphic character of the proposed sites must be known to ensure a fair trade. Comparable types of FPZs should ideally be matched when trading environmental degradation in one location for rehabilitation elsewhere. Moreover, to predict mitigation benefits, one should know how the nature of the existing mitigation site will change in response to the mitigation techniques and what the consequences will be to ecological functions and ecosystem services in the near and more distant future.

It is not uncommon for negotiations on mitigation/ rehabilitation to limit discussions to the immediate physical impact area-for legal reasons or simply because of unappreciated, corollary environmental consequences. Strong downstream impacts of upstream alterations of rivers are likely, however, and upstream biotic effects are possible, such as effects on migration by diadromous fishes. Moreover, physical changes in channel stability can spread up- and downstream, as observed in the Homochitto River of Mississippi where changes from sand-bed modifications continued to occur for at least 50 years and were manifested as far as $50 \mathrm{~km}$ upstream (Kesel and Yodis 1992). The spatial extent of the environmental impacts up- and downstream will depend on the degree and area of mitigation-rehabilitation, a site's environmental characteristics, and the organisms using or passing through it. Understanding the entire river's FPZ distribution could help predict up- and downstream impacts.

\section{Rehabilitation and restoration: Eco-forecasting and hindcasting}

Many environmental, economic, and sociopolitical factors contribute to negotiations on river rehabilitation. Decisions may be made on the basis of the uniqueness of surrounding watershed attributes, the need to preserve certain species, or the desire to promote specific services. Cost factors are related to land purchase and engineering requirements. Cost/benefit calculations become more complicated in instances of "ecosystem services disconnect." That is, some important services may be manifested downstream rather than in the immediate rehabilitation area. For example, suppose a levee in the middle Mississippi River is set back to increase channel complexity, the lateral extent of the river's wetted area, and the resulting amount of low- to zero-flow area. An adjacent town may see 
little direct value of increases in water storage and bacterial denitrification in expanded slackwater areas. In contrast, downstream communities may experience less flood damage and coastal communities in southern Louisiana could benefit from increased fisheries in a spatially diminished Gulf hypoxia zone (http://www.gulfhypoxia.net).

Site selection usually emphasizes the reach-level of organization and rarely focuses at the larger-and we believe more appropriate-valley-to-reach level FPZs. Indeed, most rehabilitation projects span less than $1 \mathrm{~km}$ of river channel (Bernhardt et al. 2005). Reach-level rehabilitation cannot fully account for the river's natural shaping processes and, therefore, may be unstable and economically demanding over the long term, even if more feasible in the short term. The natural ecosystem services should be significantly greater and more diverse at the valley level.

Cost/benefit analyses of rehabilitation should take into account at least two essential ecological and hydrogeomorphic factors: (1) a river's hydrogeomorphic state in the past, present, and possible future; and (2) costs and benefits of incremental rehabilitation for different types of FPZs.

First, one should ask, "What are the historical and present hydrogeomorphic structures of the river in that area and how would the structure change in the immediate area, as well as up- and downstream over multiple years under various rehabilitation scenarios?" A remote sensing-based rivertyping approach could help provide perspectives on the possible historical structure of the river, although onsite analysis of sediment profiles may be required to gain a more accurate picture for situations where the channel and near-valley components have been changed substantially (cf. Walter and Merritts 2008). However, the potentially valuable techniques for environmental hindcasting and forecasting need refinement.

Second, one should ask, "What are the cost/benefit ratios of incremental rehabilitation for different types of FPZs?" Computing monetary prices for management actions is relatively straightforward (e.g., Bernhardt et al. 2005) in comparison to assigning value to end benefits because the costs of deploying equipment and manpower are relatively easy to calculate, and land purchase costs are directly related to the amount of needed and its market value. Predicting the value of ecosystem services is more challenging because (a) assigning monetary value is difficult for inherently qualitative services; (b) costs may accrue and benefits may develop in spatially disconnected ways (i.e., ecosystem services disconnect); (c) some services may have emergent properties and be evident only when vitally linked services are present; $(\mathrm{d})$ the potential presence and value of different services will vary greatly with FPZ type (table 1); (e) potential time delays may exist between the engineering component of rehabilitation and investment returns; and (f) the production of services is often a nonlinear function of the extent of rehabilitation, and the cost/benefit curve will vary with service type. The last two factors are discussed below.
Spatiotemporal variability, a feature of most ecosystems and their services, must be fully characterized to predict ecosystem benefits. This variability may preclude valuation of services immediately following rehabilitation, and management actions can have variable consequences depending on where and when they are implemented. For rivers, flow often varies substantially among and within ecoregions over time, confounding short-term observations and quantification of services.

The cost of restoring a river segment to its quasi-natural form is nonlinear and will vary with FPZ type and both land and engineering requirements. Differences in cost/benefit ratios by FPZ type are illustrated for anastomosing, meandering, and constricted FPZs in figure 2, which shows different average slopes and possible complexity patterns for this ratio. (Please note that figures 2 and 3 are not meant to be used literally, but should serve instead as an heuristic guide representing some of the issues that should be considered in any rehabilitation project.) On the basis of our conclusions and predictions from the RES (Thorp et al. 2008), one would initially predict that the benefits derived would be greatest for the anastomosing FPZ. The results, however, might be much more complicated, because the new form adopted by the

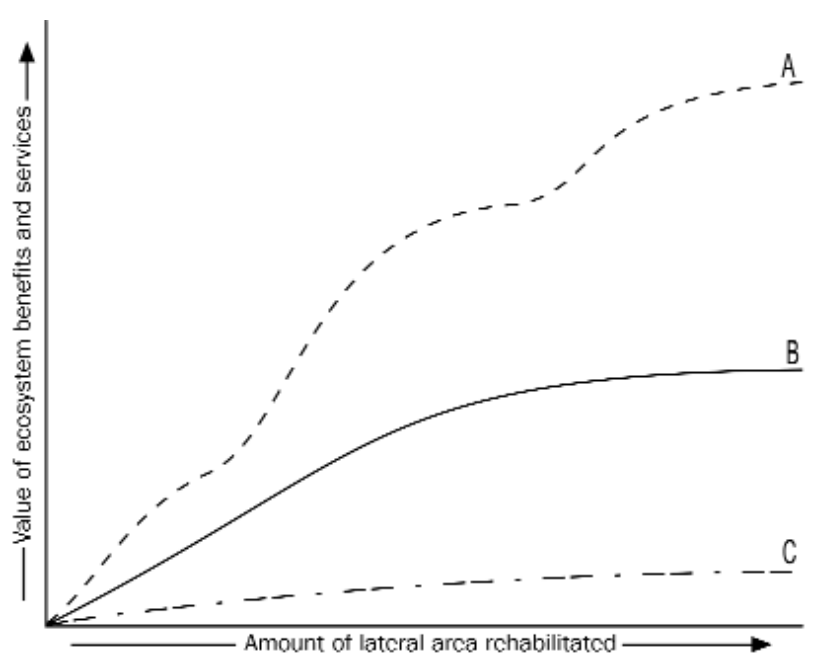

Figure 2. Hypothetical graph illustrating the nonlinear effects of rehabilitation on a single-channel, leveed river at sites where the original functional process zone (FPZ) was characterized by either anastomosing (a), meandering (b), or constricted (c) channels. The y-axis shows the value obtained in total benefits and services for different levels of financial investments ( $x$-axis) in moving a levee variable distances laterally from the main channel. Costs and benefits are for a fixed time period, with the slope of the lines varying with local engineering costs, land values, and types of services obtained and locally valued for these sites (see figure 3). The graph is not meant to be used literally but instead is meant as a guide to some of the issues that should be considered in any rehabilitation project. 


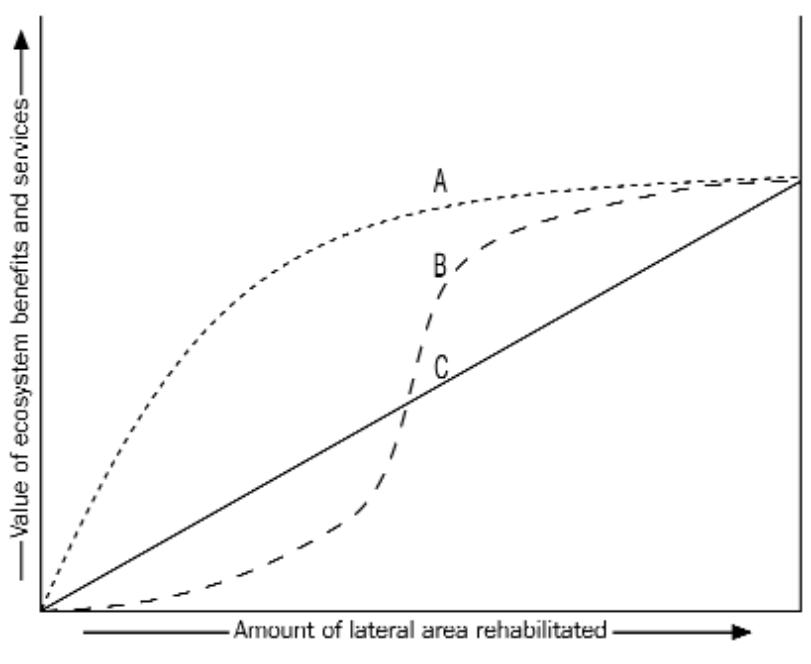

Figure 3. Hypothetical graph illustrating the nonlinear effects of rehabilitation on a single-channel, leveed river for different bundles of ecosystem benefits and services in an area whose original functional process zone included anastomosing channels. The bundled services might represent, for example: (a) recreation and production of food and fiber; (b) denitrification and carbon sequestration; and (c) water and sediment storage. Costs and benefits are for a fixed time period, with the slope of the lines varying with local engineering costs, land values, local value assigned to different services, and type of original functional process zone at the rehabilitated site (see figure 2). The graph is not meant to be used literally but instead is meant as a guide to some of the issues that should be considered in any rehabilitation project.

channel could depend on how far back the levees were set, and whether the original FPZ could be restored for hydrologic or other reasons.

Nonlinearity in the cost/benefit ratios for rehabilitation and production of ecosystems services is also related to the type of services evaluated. Figure 3 illustrates some hypothetical relationships between the rehabilitation cost and the value of ecosystem services accrued for three service bundles. Services that cannot easily be assigned a dollar value, even if intrinsically important (e.g., aesthetic and spiritual values, protection of endangered species, and promotion of biodiversity), are not included here. Costs are primarily due to land costs and, secondarily, to engineering demands. The dashed or dotted lines show returns in benefits. These illustrate three of many potential relationships and are not meant to be exact. The limited literature on such relationships suggests that the value of services might rise steadily to an asymptote or peak (as in line A of figure 3), and then level off or decline thereafter (e.g., Koch et al. 2009). In figure 3 , however, we present two other scenarios. There are several explanations for these different responses that perhaps can be best explained for a multichannel anastomosing segment.
For the bundle consisting of recreation and food and fiber production (line A), only a few side channels are necessary for safer (slower water flow) and more secluded areas for recreation (e.g., boating and recreational fishing); the accrued value will increase somewhat with a larger lateral area, but at some point the line for the cost/benefit ratio stops rising and probably eventually declines. For the bundle of water and sediment storage (line B), the greater the lateral area, the higher the value up to the valley flood limit. Finally, for the bundle of denitrification and carbon sequestration (line $\mathrm{C}$ ), the value might be low initially (e.g., insufficient amount of backwaters with anoxic sediments), then rise rapidly, before leveling off and perhaps even declining. These relationships will vary among FPZs located in different geographic regions with dissimilar population densities and cultural values.

We believe it is important to understand the relationship between the hydrogeomorphic character of a river section and the services it provides, and also to comprehend the likely effects of altering natural and regulated river FPZs. Cost/benefit ratios of rehabilitation will vary with type of FPZ (present and target), the type of services most valued in a given area, and the amount of rehabilitation undertaken. Optimization algorithms, which are often employed for site selection of protected or conservation areas subject to multiple conditions or constraints (Sala et al. 2002, Lawler et al. 2003, Beech et al. 2008), may have a significant potential for optimizing river rehabilitation and management strategies. In all cases, understanding the hydrogeomorphic structure and ecological relationships of rivers at the level of functional process zones is vital for the immediate site and for areas upstream and downstream of any rehabilitation project.

\section{Acknowledgments}

Support for an ecosystem services workshop came from the EPA's Office of Research and Development, a National Science Foundation EPSCoR grant to the University of Kansas (EPS0553722; Kristin Bowman-James, primary investigator), and the University of Kansas's Kansas Biological Survey. We thank Greg Toth and two reviewers for comments on an earlier manuscript.

\section{References cited}

Beech T, Dowd M, Field C, Hatcher B, Andréfouët S. 2008. A stochastic approach to marine reserve design: Incorporating data uncertainty. Ecological Informatics 3: 321-333.

Benda L, Poff LR, Miller D, Dunne T, Reeves G, Pollock M, Pess G. 2004. Network dynamics hypothesis: Spatial and temporal organization of physical heterogeneity in rivers. BioScience 54: 413-427.

Bernhardt ES, et al. 2005. Synthesizing US river restoration efforts. Science 308: 636-637.

Brinson MM 1993. A Hydrogeomorphic Classification for Wetlands. US Army Corps of Engineers, Waterways Experiment Station. Technical Report WRP-DE-4.

Casper AF, Thorp JH, Davies SP, Courtemanch DL. 2006. Ecological responses of zoobenthos to dam removal on the Kennebec River, Maine, USA. Archiv für Hydrobiologie, Large Rivers 16: 541-555.

Costanza R. 2008. Ecosystem services: Multiple classification systems are needed. Biological Conservation 141: 350-352. 
Daily GC, Polasky, S, Goldstein J, Kareiva PM, Mooney HA, Pejchar L, Ricketts TH, Salzman J, Shallenberger R. 2009. Ecosystem services in decision making: Time to deliver. Frontiers in Ecology and the Environment 1:21-28.

Frissell CA, Liss WJ, Warren CE, Hurley MD. 1986. A hierarchical framework for stream habitat classification: Viewing streams in a watershed context. Environmental Management 10: 199-214.

Galat DL, Zweimüller I. 2001. Conserving large-river fishes: Is the highway analogy an appropriate paradigm? Journal of the North American Benthological Society 20: 266-279.

Hein T, Baranyi C, Herndl GJ, Wanek W, Schiemer F. 2003. Allochthonous and autochthonous particulate organic matter in floodplains of the River Danube: The importance of hydrological connectivity. Freshwater Biology 48: 220-232.

Kesel RH, Yodis EG. 1992. Some effects of human modifications on sandbed channels in southwestern Mississippi, USA. Environmental Geology and Water Sciences 20: 93-104.

Koch EW, et al. 2009. Non-linearity in ecosystem services: Temporal and spatial variability in coastal protection. Frontiers in Ecology and the Environment 1: 29-37.

Lawler JJ, White D, Master LL. 2003. Integrating representation and vulnerability: Two approaches for prioritizing areas for conservation. Ecological Applications 13: 1762-1772.

Loomis J, Kent P, Strange L, Fausch K, Covich A. 2000. Measuring the total economic value of restoring ecosystem services in an impaired river basin: Results from contingent valuation survey. Ecological Economics 33: $103-117$

[MEA] Millennium Ecosystem Assessment. 2005. Ecosystems and Human Well-being: Wetlands and Water Synthesis. World Resources Institute.

Montgomery DR. 1999. Process domains and the river continuum concept. Journal of the American Water Resources Association 35: 397-410.

Naidoo R, Balmford A, Costanza R, Fisher B, Green RE, Lehner B, Malcom TR, Rickets TH. 2008. Global mapping of ecosystem services and conservation priorities. Proceedings of the National Academy of Sciences 105: 9495-9500.

Nelson EG, et al. 2009. Modeling multiple ecosystem services, biodiversity conservation, commodity production, and tradeoffs at landscape scales. Frontiers in Ecology and the Environment 1: 4-11.

Poff NL, Allan JD, Bain MB, Karr JR, Prestegaard KL, Richter BD, Sparks RE, Stromberg JC. 1997. The natural flow regime: A paradigm for river conservation and restoration. BioScience 47: 769-784.

Poole GC. 2002. Fluvial landscape ecology: Addressing uniqueness within the river discontinuum. Freshwater Biology 47: 641-66.

Plummer ML. 2009. Assessing benefit transfer for the valuation of ecosystem services. Frontiers in Ecology and the Environment 1:38-45.

Postel S, Carpenter S. 1997. Freshwater ecosystem services. Pages 195-214 in Daily GC, ed. Nature's Services: Societal Dependence on Natural Ecosystems. Island Press.

Ricciardi A, Rasmussen JB.1999. Extinction rates of North American freshwater fauna. Conservation Biology 13: 1220-1222.

Rice SP, Greenwood, MT, Joyce CB. 2001. Tributaries, sediment sources, and the longitudinal organization of macroinvertebrate fauna along river systems. Canadian Journal of Fisheries and Aquatic Sciences 58: 824-840.
Roach KA, Thorp JH, Delong MD. 2009. Influence of lateral gradients of hydrologic connectivity on trophic position of fishes in the upper Mississippi River. Freshwater Biology 54: 607-620.

Rosgen DL. 1996. Applied River Morphology. Wildland Hydrology.

Sala E, Aburto-Oropeza O, Paredes G, Parra I, Barrera JC, Dayton PK. 2002. A general model for designing networks of marine reserves. Science 298: 1991-1993.

Schwartz MW, Brigham CA, Hoeksema JD, Lyons KG, Mills MH, van Mantgem PJ. 2000. Linking biodiversity to ecosystem function: Implications for conservation ecology. Oecologia 122: 297-305.

Stahkiv E, Cole R, Scodari P, Martin L. 2003. Improving Environmental Benefits Analysis. Institute for Water Resources, Policy Studies Program, US Army Corps of Engineers. IWR Report 03-PS-3.

Thoms MC, Parsons M. 2003. Identifying spatial and temporal patterns in the hydrological character of the Condamine-Balonne River, Australia, using multivariate statistics. River Research and Applications 19: 443-457.

Thoms MC, Rayburg S, Neave M. 2007. The physical diversity and assessment of a large river system: The Murray-Darling basin, Australia. Pages 587-608 in Gupta A, ed. Large Rivers. Wiley.

Thorp JH, Thoms MC, Delong MD. 2006. The riverine ecosystem synthesis: Biocomplexity in river networks across space and time. River Research and Applications 22: 123-147.

. 2008. The Riverine Ecosystem Synthesis. Academic Press.

Townsend CR, Hildrew AG. 1994. Species traits in relation to a habitat templet for river systems. Freshwater Biology 31: 265-275.

Turner WR, Brandon K, Brooks TM, Costanza R, da Fonseca GAB, Portela R. 2007. Global conservation of biodiversity and ecosystem services. BioScience 57: 868-873.

Vannote RL, Minshall GW, Cummins KW, Sedell JR, Cushing CE. 1980. The river continuum concept. Canadian Journal of Fisheries and Aquatic Sciences 37: 130-137.

Walter RC, Merritts DJ. 2008. Natural streams and the legacy of waterpowered mills. Science 319: 299-303.

James H. Thorp (thorp@ku.edu) is a professor in the Department of Ecology and Evolutionary Biology (EEB) and senior scientist at the Kansas Biological Survey (KBS), and Ford Ballantyne is an assistant professor in EEB and an assistant research scientist in KBS, both at the University of Kansas, in Lawrence. Joseph E. Flotemersch is a fluvial ecologist with the US Environmental Protection Agency, Office of Research and Development, in Cincinnati, Ohio. Michael D. Delong is a professor in the Department of Biology at Winona State University, Minnesota, and is director of the Large River Studies Center. Andrew F. Casper is a research biologist in the Aquatic Ecology and Invasive Species Branch of the Environmental Lab at the US Army Corps of Engineers Waterway Experiment Station, in Vicksburg, Mississippi. Martin C. Thoms is a professor in the Faculty of Applied Science and is director of the Riverine Landscapes Research Laboratory, at the University of Canberra, Australia. Bradley S. Williams and Brian J. O'Neill are doctoral students in the EEB at the University of Kansas. C. Stephen Haase is a senior biohydrologist with the southern US region of the Nature Conservancy, in Rockwood, Tennessee. 